\title{
THE ANALYSIS OF SUBJECT-VERB AGREEMENT ERRORS ON STUDENTS' WRITING DESCRIPTIVE TEXT
}

\author{
Nafisatul Hasanah ${ }^{1}$ \\ ${ }^{1}$ English Teaching Learning Program, Faculty of Tarbiyah, Institut Agama Islam Negeri Madura, \\ Pamekasan 69371, Indonesia \\ (nafisatulhasanah18@gmail.com) \\ Mosleh Habibullah ${ }^{2}$ \\ 2English Teaching Learning Program, Faculty of Tarbiyah, Institut Agama Islam Negeri Madura, \\ Pamekasan 69371, Indonesia \\ (moslehhabibullah@gmail.com)
}

\begin{abstract}
Subject-verb agreement is a language system that is learned by students who study English, yet some students like the eighth graders of MTs Sunan Kalijaga still make errors in applying this rule in their writing. This study is aimed to find out the subjectverb agreement errors on students' writing descriptive text in the eighth grade in MTs Sunan Kalijaga Larangan Luar Larangan Pamekasan and to know the factors which cause their errors. In this research, the researcher used a qualitative approach with content analysis and descriptive design. The data was obtained by observing the descriptive texts written by the eighth graders. Then, discussing and analyzing the subject-verb agreement within the writing. After knowing the errors, some students and the teacher were interviewed to know the factors which cause such errors. Documentations were also used to legitimize the data. From 25 texts which were collected by the researcher, there are 92 omission errors in subject-verb agreement, 22 addition errors, 44 misformation errors, and 3 misordering errors. Additionally, those kinds of errors are caused by two main factors, namely word for word translation and the lack of grammar. Those factors relate to interlingual and intralingual factors. In brief, there are still many errors of subject-verb agreement among the students' writing of descriptive text in the eighth grade in MTs Sunan Kalijaga.
\end{abstract}

Keywords: Descriptive Text; Error Analysis; Subject-Verb Agreement

First Received:

(June 06, 2020)
Final Proof Received:

(September 15, 2020)

\section{INTRODUCTION}

Grammar is one of the language aspects which is very important to be learned, especially in English. It is needed for some skills in English, particularly in writing. Grammar in writing is very crucial because it can influence the order of the words and the meaning expressed. When a language user uses good grammar in a sentence, the desired meaning will be easier to be understood. Contrarily, the use of wrong grammar will cause the reader to confused or catches different meanings. The problem is on the writer itself, who cannot use grammar correctly. It is usually called as an error.

The grammatical error can be found in many kinds of writing, especially the writing of beginners, such as diary, short story, narrative text, descriptive text, and others. It is 
caused by the knowledge which is mastered by the students. Lack of grammar knowledge can cause many errors in writing any texts. One of the errors which usually happens among students in the level of a beginner is a subject-verb agreement, which is the inability to match the form of the subject and the verb following it.

Subject-verb agreement refers to the use of subject and verb which must be in line in singular and plural (Eastwood, 1994: 191). If the subject is in the singular form, the verb must be in the same form and vice versa. If the subject is in plural form, the verb must be plural. This aspect of grammar becomes a common problem for English learners (Reid, 1982: 167), because there are still many errors that often occur in this aspect. While the error itself is defined as a case in which the language learner does not know the correct grammar which should be used (Ellis, 1997: 17). It can cause the sentence made more difficult to be understood and can be interpreted differently from the desired meaning because the existence of grammar is as basis and formula in arranging words to be a meaningful sentence or to show the probable structure used in a language (Thornbury, 1999: 1). An error that is found in the subject-verb agreement aspect is called a subjectverb agreement error. This kind of error can be found in any writing of the students, as found in descriptive text.

Descriptive text is a kind of text which describes something, someone, or place. In writing descriptive text, the students should know how to describe the subject, whether using the nominal form or using the verbal form of the sentence. Both of the sentence form in the descriptive text requires the knowledge of the subject-verb agreement, that is to determine the appropriate verbs for a certain subject. But, errors still can be found in the text. To identify the subject-verb agreement error in the students' writing, it needs a process to analyze it, namely analysis of subject-verb agreement errors.

The study of error analysis has been widely executed by many researchers, as conducted by Wahyudi who has analyzed subject-verb agreement errors on students' writing in the first semester in English Department Maulana Malik Ibrahim State Islamic University (Wahyudi, 2012: 20). Similarly, Nurjanah has completed her research on a similar topic among the students of the second semester at Muhammadiyah University Yogyakarta (Nurjanah, 2017: 13). Another researcher is Chele who has analyzed subject agreement errors in third-year students at the National University of Lesotho (Chele, 2015: 32). Among the previous studies mentioned above, the subjects of the research were university students which indicate high-level students. They have learned subject-verb agreement many times as they have passed English subject since junior high school. It is only to investigate their errors but less of preventing and avoiding the errors, even improving their understanding, because they have been on the advanced level, not a beginner. This research is conducted to study among beginners which have learned about subject-verb agreement. Those are the eighth graders of MTs Sunan Kalijaga. By analyzing their errors early, it can help them in avoiding such errors for the next lessons. 
This research is carried out based on the phenomena found among the students in the eighth grade in MTs Sunan Kalijaga Larangan Luar Larangan Pamekasan. Although there is an English course for the students there, especially on Wednesday night, Saturday night, and Fasting Month, the students still make errors in using the subject-verb agreement. They have already learned about the subject-verb agreement which is covered in tenses material, especially in the simple present tense, but they still cannot use the rule appropriately as found in Fikri's writing: "A bell ring loudly". The sentence contains subject-verb agreement errors, which is the omission of $-\mathrm{s}$ which indicates the singularity of the verb which is needed to match with the singular subject.

From the example above, it is a need to explore more about the errors they make when they write a text like descriptive text, specifically in subject-verb agreement. Certainly, it should be revealed through the research of error analysis. Therefore, the researcher is interested in analyzing subject-verb agreement errors on students' writing descriptive text in the eighth grade in MTs Sunan Kalijaga Larangan Luar Larangan Pamekasan.

\section{LITERATURE REVIEW}

\section{Definition of Error Analysis}

One of the problems which occur among language learners is they make an error in using the language they learn. Lexically, the term error can be defined as the accident was done to human ("Oxford Learner's Pocket Dictionary," 2008: 150). Errors reflect gaps in learners' knowledge in which the learners make errors because they do not know the right rules which should be used by them (Ellis, 1997: 17). In this case, the language learner cannot produce the language correctly.

Error is the real situation in which the language learner does not know the correct rules and they cannot do self-correction. It should differ from the mistake, where mistake refers to a performance error that is either a random guess or slips in that it is a failure to use the known system correctly (Brown, 2007: 257). In mistake, the language learners know the system of the language, but there are some factors which influence them so that they cannot use their understanding appropriately for the language. This kind of problem is self-corrected. They can realize their mistakes when someone tells them about that and able to correct it. In brief, errors and mistakes are different.

Errors of language learners sometimes cannot be predicted by the teacher or linguist (Richards, 1974: 19), because the learners' comprehension of the language system is various. Besides, an error is also considered as something undesirable, because the learners are failing to differentiate between the use of the first language and the second language, besides unable to use it appropriately based on their own rules (Ellis, 2015: 22). Therefore, it is a need for the teacher to investigate the error of the students to find the 
solution. This step can be done by analyzing the error itself. It is usually called as error analysis.

Error analysis is the process of observing, analyzing, and classifying the errors of learners to reveal something of system operating within the learner, lead to a study of learners' errors (Brown, 2007: 259). Error analysis here can be conducted from the simplest thing, that is collecting the sample of the language learner, then identifying errors, describing errors, explaining errors, and evaluating the error itself (Ellis, 1997: 1720). Those steps can be used by the teacher to find out the errors made by the students, the possible factor which influences them, and the possible solution to solve those problems.

\section{Kinds of Error}

The term error is broadly used for many kinds of errors that are made by language learners. In a different time, a language learner may produce different errors, moreover between one learner with others. They may produce different errors because of their different knowledge and capability in comprehending the system of language. Error is divided into four kinds, those are omission, addition, misinformation, misordering (Dulay, Burt, \& Krashen, 1982: 150). The kinds mentioned above are explained as follows:

The first, omission is a kind of error in which the language learner omits one or some parts of the language system. There some possible parts which are omitted by the learner, they are auxiliary verb (such as "She smart" which omits auxiliary "is" after the subject); inflectional morpheme for noun or verb (such as "She always get up at 4 o'clock" which omits the inflectional -s for the verb. The correct one is "gets up" because the subject is a third singular person and the tense is simple present); article (such as "Stranger man came to my house yesterday". In this sentence, the learner omits an article which precedes the subject, that is "A stranger"); preposition (such as "I go school" instead of "go-to").

The Second, addition which is a kind of error in which the language learners add something to the language system which is unnecessary and causes the language produced becomes incorrect. In specific, addition error is divided into three kinds, those are: double markings, is a case in which the language learner does not delete certain items which are required in some linguistic system, but not in others; for example, "She does not comes to the class today"; regularization, is a kind of error in which the language user applies similar rule for some items by adding something regularly for an irregular item, such as "She putted the book on the table". The use of "putted" instead of "put" as the past form of the verb indicates an error; simple addition is a kind of addition error which do not include double marking or regularization, such as "I goes to library every Monday".

The third, misformation is a kind of error in which the language learners use the wrong form of the morpheme or structure. This kind of error has been specified into three kinds, namely regularization errors, that is the use of regular marker for the irregular 
items; for example, "She has two childs". The use of "childs" is incorrect because the plural form of child is "children"; archi-forms, is the use of one item to represent others which have similar classes, such as "What does your hobby?". In this case, the use of "does" is incorrect, the correct one is "do". Although they are in a similar class as an auxiliary verb, they have different usage relates to the subject, and the sentence above should use "do"; alternating forms, that is a kind of misformation errors in which the language learner uses another various member of a class, like the use of "she" which replaces "her" in a sentence "She dress is very expensive".

The fourth, misordering which is a kind of error in which the language learners misorder some words in a sentence. They cannot place the words appropriately; for instance, "I saw a motorcycle black in front of your house yesterday". The phrase "a motorcycle black" is misordered, the correct one is "a black motorcycle".

Besides those kinds of errors, there is another categorization that divides errors into global error and local error (Brown, 2007: 263). The global error refers to an error in which the language learners produce sentences ungrammatically and its meaning cannot be interpreted since the structure of the sentence is unclear, such as "The policeman was in the corner whistle....". This sentence is not understandable because it is produced ungrammatically. While the local error is a kind of error in which the language learner produces a minor mistake in using grammar, but it is still understandable; for example, "May I borrow a scissor?", in this example scissor is the grammatically plural form, "scissors", but if it is said to be singular and preceded by the article "a", it is an error although the hearer or reader still can understand the desired meaning.

\section{Source of Error}

Errors that occur among the learners of the second language are commonly caused by the transfer between the first language into the second language. Both of them may have similarities and differences. If the first language has contrastive or different rules from the second language, it can be an inhibition for the learner in the learning process. The differences will cause the learner to confused and often make errors because they arrange the words in the second language based on the rules that they know in the first language. The case which is described above usually called negative transfer (Ellis, 2015: 22). It becomes the problem for the learner because they have no right to determine the rule of the second language they need.

On the other hand, the transfer from the first language into the second language can be a positive one, called a positive transfer (Ellis, 2015: 22). It happens when the rules of the first language and the second language are almost similar so that the learners will be easier to use or arrange words of the second language because they have understood the similar rules for the language. Therefore, the process of learning can run smoothly and the learners develop their skills or improve knowledge rapidly. 
Specifically, Brown states that some factors can cause an error in language learning, namely interlingual transfer, intralingual transfer, the context of learning, and communication strategies. The explanations are below:

The first factor is an interlingual transfer, it is the factor that influences the most common error which happens in the early stage of learning a second language. Language learners who learn new languages are usually influenced by the interference of the first language in producing the second language. It is a significant source of errors for all learners. Before the language learners understand well about the second language system, they will transfer their first language system in using the second language. This factor influences the language learner when the transfer is negative, that is the system for both languages is different, consequently, errors are produced.

The second factor is the intralingual transfer, it is the source of error in the target language. After the learners understand some second language system, they use the rules they know for many kinds of sentences. When they know a rule, they can use it for a sentence which has a different rule. It is also called as a generalization within the target language, because they cannot use the system of language properly, such as "I don't know what time is it". At the example, the noun clause has a structure like a question form, which is auxiliary precedes the subject. It is an error since the right form is like a statement. The learners may produce it because they know that "what" is a question word, and the pattern to use it is followed by an auxiliary, then the subject itself. another condition shows the error caused by intralingual transfer are the use of a past form of a verb after a modal, past form of the verb following "do", v-ing following a modal.

The third factor is the context of learning. It refers to the context which surrounds the learning process which is experienced by language learners, such as the teacher or the textbook. Both of them can lead the learner to make a faulty understanding of the language, or it is called false concepts or induced errors. In this case, the learners may learn in the class where a person becomes the teacher, then the learners make their different assumptions or hypothesis about the material taught by the teacher, so they will misunderstand the material. Besides, it can also be caused by the textbook when the language learners learn by themselves and they misinterpret the information contained in the book, so they will produce errors because of knowing wrong information or knowledge.

The last factor is communication strategies. It refers and relates to learning style. Learners use a particular strategy in delivering their desired meaning, but sometimes, the way they express it can be the source of error; for example, a learner said, "Let us work for the well done of our country". This sentence had an incorrect approximation of the word "welfare" (Brown, 2007: 263-266). 


\section{Subject-Verb Agreement}

One of the grammar discussions is subject-verb agreement. As common stated by experts and known by language learners, subject and verb are the main part of the sentence which cannot be separated. There is a specific rule which governs about them, called a subject-verb agreement.

The term "subject" can be defined as a noun or pronoun which does an action, while "verb" is a word that indicates action or state of being (Straus, 2008: 1). On the other hand, the term "agreement" is considered as selecting a subject that agrees in person and number with the verbs, and select pronouns that agree in person and number with reference noun and other pronouns (Basri, 2009: 76). In other words, the agreement means using a singular verb after a singular or uncountable subject and a plural verb after a plural subject (Eastwood, 2008: 184). In this definition, an agreement is defined as the concordance between the subject and verb whether in terms of number or person. Such a definition also proposed by Roberts, in which he states that subject-verb agreement is the general rules in which the verb must agree with the subject in number (Roberts, 1954: 275). If the subject is singular, the verb following it should be in a singular form and is the subject is plural, the verb must be in plural form.

Similarly, another definition is stated that subject-verb agreement is choosing the appropriate singular or plural verb after the subject (Eastwood, 1994: 191). The main point is similar, that is subject and the verb must have a similar form in number. Although this rule seems to be simple, it does not cause the language learners confused in determining whether the verb used should be singular or plural. There are some rules which should be considered about the subject-verb agreement as follow:

The first, Singular subject is followed by a singular verb. A singular subject can be the base form of a noun or singular noun (no plural marker); some words such as everyone, someone, anyone, no one, each, everybody, somebody, anybody, nobody, nothing, anything, something, everything (Roberts, 1954: 281); pronoun "it" (Djuharie, 2008: 36); some words which seem to be plural but exactly are singular like the name of the subject (economics, mathematics, physics, statistics, civics, linguistics), the mane of disease (measles, mumps, herpes), abstract noun (news, ethics, politics); the title of the book, music, newspaper; noun which is formed by adding -ing to verb (Djuharie, 2008: 36-37). Those kinds of nouns or pronouns require a singular verb.

The second, plural subject is followed by a plural verb. There are some conditions where the subject is called as plural, they are two or more phrases which are linked by "and", "both... and" (Eastwood, 1994: 192); noun which is preceded by a quantifier which indicates plurality, such as both, many, several, few, etc; some words which consistently as plural, such as clothes (trousers, pants, jeans, sunglasses), tools (scissors, pliers, tweezers), abstract noun (riches, thanks, means). Subjects with those conditions should be followed by a plural verb. 
The third is a subject that requires a singular or plural verb. There are some cases where the subject requires singular or plural verb based on the context it is used, the condition are: a subject which is linked by "either/ neither... or/ nor", "not only ... but also" requires verbs which are in line with the nearer subject, such as "Neither the students nor the teacher comes to the class today"; a subject which contains prepositional phrase requires verbs which are in line in number with the nouns precedes the prepositional, such as "the increase of criminal numbers causes citizen worried"; some words, such as "all, some, majority, none, most, half" if followed by a prepositional phrase, the verbs required is determined by the nouns following the preposition; a subject which is preceded by "a number of" requires plural verbs, while subject which is preceded by "the number of" requires singular verbs; collective nouns usually need a singular verb, such as class, team, police, committee, audience, family, faculty, etc; some words have a similar form of singular and plural, such as species, series, sheep, deer, so the verb which follows them are determined by the attribute of the noun itself (Djuharie, 2008: 38-39).

Those are some rules which should be understood to have a good subject-verb agreement, but it will be useless if the language learner does not know and understand well the form of singular and plural noun and verb, therefore, language learner also should know how noun and verb are called as singular or plural.

A noun is usually called singular where the noun is only one and in the ordinary form without any addition, while for a plural noun, it refers to a noun which is more than one in number. It is usually indicated by the use of plural marker. There are some indicators of plural noun, they are: the first, inflectional morpheme -es for noun which is ending in "ch, s, sh, $\mathrm{x}$ ", such as: bus-buses; the second, inflectional morpheme -es for noun which is ending in "o", such as: potato-potatoes, but some of them is added with -s, such as: radio-radios; the third, the change of "y" into "-ies", such as: baby-babies; the fourth, inflectional morpheme $-\mathrm{s}$ for noun which is ending in " $\mathrm{y}$ " and preceded by vowel, such as: key-keys; the fifth, the change of "f/fe" into "-ves", such as: wife-wives, but some of them only requires - s, such as: roof-roofs; the irregular noun, such as: foot-feet (Fanani, 2014: 48-51).

Besides the noun, the verb also can be identified as its singularity or plurality. Basically, verb which follows a subject can be in form of ordinary verb and auxiliary verb. The first is ordinary verb. in this case, singular and plural verbs can be differentiated in the simple present tense, where for subject "I" and plural subject, the verb following should be the base form of the verb, while for the singular subject, the verb following should be added with -s/es. Verb ending in "-ch, -c, -ss, -sh, -o" usually added by -es; verb ending in "-y" which is preceded by consonant usually changed into "-ies"; and verb ending in "-y" which is preceded by vowel usually added by -s (Roziqin, 2013: 48-49). The second is auxiliary verb. It has many kinds of word with different usage. The auxiliary verb, "is/am/are", is used in simple present tense, especially "is" for singular subject, "are" for 
plural subject, and "am" for pronoun "I"; "Was/were" is used for past tense where "was" for singular subject and "were" for plural subject; "Do/does" is used in negative and interrogative sentence of present tense, "do" follows subject "I" and plural subject, while "does" follows the singular subject; "Has/have" is used for perfect tense where "has" follows singular subject and "have" follows plural subject and "I"; other auxiliaries are "did" and modal auxiliary which are used for all kinds of subject (Vince, 2008: 14).

\section{Descriptive Text}

One of the texts which are taught for students to write is descriptive text. It can be found in some levels or grades. To know more about descriptive text, it is a need to begin by knowing the definition of the descriptive text itself. From the term descriptive, it can be known that this word is derived from the word "describe", that is say what somebody or something is like ("Oxford Learner's Pocket Dictionary," 2008: 120). It gives representation about the characteristic of something.

From the lexical meaning above, descriptive text can be defined as a kind of text which describes the characteristic of particular person, thing, or place specifically (AU, 2010: 92). It describes how person, thing or place looks like, what is the characteristic, etc. other definition shows that descriptive paragraph or descriptive writing is kind of writing which explains how someone or something looks or feels (Zemach \& Rumisek, 2005: 25). It is in line with its purpose, that is to provide detail or show the characteristic of what we are referring to. By using descriptive text, the writer can tell about something without showing the picture, by giving the specification of the person, thing, or places, such as the color, shape, size, and others. Descriptive text can show the detail of the person, from the physical even the character itself. It is also applied for a place or thing that is described. It can be from physical aspects or non-physical aspects.

As a kind of text, the descriptive text has its own structure. Knowing the structure of the text can make the learners able to write it in ease. Text structure is term refers to the way a text is organized to guide readers in identifying key information (Klingner, Vaughn, \& Boardman, 2007: 76). Texts are organized in different ways. Because of that, the generic structure of descriptive text is different from others. There are two parts or generic structure of descriptive text namely identification and description (AU, 2010: 93). The first, identification or called as subject introduction, is part of descriptive text which contains the general introduction about the subject which will be described, whether it is person, thing, or place. The second, description, is the main part of descriptive text which contains the description about the characteristic of the subject which is described, such as physical description, quality, behavior, and other unique characteristics which cause the subject different with others.

Besides having generic structure, descriptive text also has some language features which can guide the writing of this text. The language feature used refers to the language 
choice in arranging a text. It can be a type of the sentence which can support the process of delivering the meaning.

Here are some language features of descriptive text: use a particular noun, that is the noun which is used as subject should be specific by using determiners, possesive words, such as my car, my pet, my new house; the subject which will be described is unique so that within the text, it can be differentiated with others by showing its uniqueness; use simple present tense, such as I live in a simple house; use detailed noun phrase to describe something in details, such as I have a white-skinned girlfriend; use many kinds of adjective which can describe, number, and classify the subject like two strong legs; use thinking verb and feeling verb to express the writer's opinion about the subject described, such as I think, I feel; use action verb, such as my cat eats mouse; use figurative language (simile, metaphor), such as John is white as chalk (AU, 2010: 93).

\section{METHOD}

This research used qualitative research, especially content analysis and descriptive design. Content analysis is used to find out the subject-verb agreement errors within the students writing descriptive text. Next, descriptive design was used to know the factors which influence the students in making subject-verb agreement error in their writing. The main source of the data is 25 students in the eighth grade in MTs Sunan Kalijaga Larangan Luar Larangan Pamekasan. It becomes the main source because the researcher would like to analyze their writing of the descriptive text. The researcher also needs to find out their opinion and reason related to the errors found in their texts. Observation, documentation, and interview were used by the researcher to collect the data.

The researcher observed the process of writing which was done by the eighthgraders in MTs Sunan Kalijaga without taking apart within the activity. Next, the researcher took documentation of the students' writing to analyze the subject-verb agreement within the text or did a document or content analysis. The last, one-on-one interview was conducted with some students and teacher to get information about factors which influence the students in making the subject-verb agreement. While for data analysis, two kinds of analysis were used, the first is content or document analysis, and the second is data analysis procedures which are proposed by Miles, Huberman, \& Saldaña (2014) involving data condensation, data reduction, and data display.

\section{RESULTS AND DISCUSSION}

\section{Results}

\section{The Subject-Verb Agreement Errors on Students' Writing Descriptive Text}

The researcher analyzed the students' writing descriptive text which consists of 25 texts. From the whole texts written by the students, there are many incorrect sentences 
from the subject-verb agreement view. The researcher classified the error based on the surface strategy taxonomy proposed by Dulay, Burt, \& Krashen, in which they stated that error is classified into four types: omission, addition, misformation, and misordering. The classification of the error found by the researcher can be seen in the following table:

Tabel 1.

The Classification of the Errors made by students

\begin{tabular}{|c|c|c|c|}
\hline No. & Kinds of Error & Sentence & Correction \\
\hline \multirow[t]{4}{*}{1.} & Omission & & \\
\hline & a. Auxiliary & $\begin{array}{l}\text { Ust. Zainal the teacher in my class. } \\
\text { She kind. }\end{array}$ & $\begin{array}{l}\text { Ust. Zainal is the teacher in my class. } \\
\text { She is kind. }\end{array}$ \\
\hline & b. Verb Inflection & $\begin{array}{l}\text { Teacher bring laptop to class. } \\
\text { Anton always buy black bag too. }\end{array}$ & $\begin{array}{l}\text { Teacher brings laptop to class. } \\
\text { Anton always buys black bag too. }\end{array}$ \\
\hline & c. Noun Inflection & $\begin{array}{l}\text { There is eight window. } \\
\text { There is two tail. }\end{array}$ & $\begin{array}{l}\text { There are eight windows. } \\
\text { There are two tails. }\end{array}$ \\
\hline \multirow[t]{3}{*}{2.} & Addition & & \\
\hline & a. Double Marking & She is has long hair. & She has long hair. \\
\hline & b. Simple addition & $\begin{array}{l}\text { Doraemon can moves fast. } \\
\text { I am like rabbit too. }\end{array}$ & $\begin{array}{l}\text { Doraemon can move fast. } \\
\text { I like rabbit too. }\end{array}$ \\
\hline \multirow[t]{4}{*}{3.} & Misformation & & \\
\hline & a. Regularization & $\begin{array}{l}\text { She haves son. } \\
\text { She teachs Indonesia Language. }\end{array}$ & $\begin{array}{l}\text { She has son. } \\
\text { She teaches Indonesia Language. }\end{array}$ \\
\hline & b. Archi-Forms & $\begin{array}{l}\text { There is two rabbit. } \\
\text { I walking in sand. }\end{array}$ & $\begin{array}{l}\text { There are two rabbits. } \\
\text { I walk in sand. }\end{array}$ \\
\hline & $\begin{array}{l}\text { c. Alternating } \\
\text { forms }\end{array}$ & $\begin{array}{l}\text { I'am happy because I has new } \\
\text { shoes. } \\
\text { I photo are beautiful. }\end{array}$ & $\begin{array}{l}\text { I am happy because I have new } \\
\text { shoes. } \\
\text { My photo is beautiful }\end{array}$ \\
\hline 4. & Misordering & My cat's name is Uzy. & My cat's name is Uzy. \\
\hline
\end{tabular}

Based on the table above, it can be known that the subject-verb agreement errors made by the students on their writing cover omission (auxiliary, verb inflection, noun inflection), addition (double marking, simple addition), misformation (regularization, archi-form, alternating form), and misordering errors. The total of the errors for each category can be seen in the table below:

Table 2.

Total of Errors

\begin{tabular}{lll}
\hline No & Types of Errors & Total Errors \\
\hline 1. & Omission & 92 items of errors \\
2. & Addition & 22 items of errors \\
3 & Misformation & 44 items of errors \\
4. & Misordering & 3 items of errors \\
\hline Total & & 161 items of errors \\
\hline
\end{tabular}


From the data above, it is clear that the highest number of errors is omission error, the second is misformation, the third is addition, and the last is misordering.

\section{The Factors Cause the Subject-Verb Agreement Errors on Students' Writing}

The researcher also investigated the factors which cause the students to make subject-verb agreement in their writing. It is done by interviewing the students and the teacher to know the students' difficulties, problem, or obstacle in writing using English. From the interview done with some students and teacher, the researcher found that there are two main points which cause them making subject-verb agreement errors, those are word for word translation and the lack of grammar.

The first, word for word translation, is the main factor which causes them difficult in writing using English. It is caused by the limitation of their vocabulary, moreover, they are still eighth graders. The students confessed that in writing an English text, such as the descriptive text here, they need to translate the sentence word for word. The students open their dictionary to look for the vocabulary then arranging the words found to be a sentence. The second, the lack of grammar, is the factor which also caused the occurrence of subject-verb agreement errors in the students' writing. This factor relates to the students understanding of subject, verb, singular, plural, and agreement itself. It has been admitted by the teacher that grammar still becomes a big problem among the students.

\section{Discussion}

\section{The Subject-Verb Agreement Errors on Students' Writing Descriptive Text}

From the result above, it has been known that the researcher found 92 omission errors, 22 addition errors, 42 misformation errors, and 3 misordering errors among 25 students' writing descriptive text.

The omission errors which are found among the text consist of some kinds. Those are the omission of auxiliary verb and omission of an inflectional morpheme. Many students omit the use of auxiliary verb after the subject in stating the condition of something, such in this sentence, "Ust Zainal the teacher... [text 1]". In that sentence, after the subject, it should be followed by an auxiliary verb becomes "Ust Zainal is the teacher....". It is a subject-verb agreement error because the student omits the verb after the subject. Another example is "She kind [text 13]". The student omits the auxiliary verb "is" which should exist after the subject "she". Such error is also mentioned by Nurjanah in which she adds auxiliary "is" for "it easier", so it becomes "it is easier" (Nurjanah, 2017: 18).

Another kind of omission error that was found by the researcher is the omission of the inflectional morpheme. This morpheme includes a noun and verb inflection. Some students made some errors by omitting verb inflectional morpheme of the verb for the third singular person or singular subject, as happens in this sentence, "Teacher bring 
laptop... [Text 6]". In this case, the verb should be added with -s to indicate singularity because the subject is singular. Another example is "Anton always buy... [Text 3]". Similarly, the student also omits the inflectional $-\mathrm{s}$ for the verb although the subject is singular, of course, it is a subject-verb agreement errors. Besides, some students omit inflectional morpheme for a noun, such as plural marker of the subject as found in this sentence, "There is eighth window [text 9]". In this sentence, the student omits the plural marker of the noun "window". It should be added with -s to indicate plurality, because this noun is preceded by quantifier of a number, that is "eighth". Besides that, the auxiliary also should be changed into plural auxiliary. As stated by Nurjanah, it often occurs in her study. She found some similar errors, such as the use of "knows" instead of "know" for subject "everybody". It shows that the use of inflectional morpheme -s is needed for the third singular person [Nurjanah, 2017: 19]. Additionally, Mbau also found same error in her study, that is the use of "provide" instead of "provides" for sentence "Tadulako University provides good facilities for its students" (Mbau, Marhum, \& Muhsin, 2014: 6).

The next error found is addition error. Some students add unnecessary item within the structure. In this kind of error, the students can create double marking and simple addition error. In the case of this sentence, "She is has long hair [text 2]", the student double marks the singularity of the verb, that is by using auxiliary "is" and verb "has" as the singular form of "have", but this construction is incorrect because the auxiliary verb here is not needed in the construction. After the subject, it should be followed by the ordinary verb becomes "She has long hair".

Besides, the student also makes simple addition error. It can be in form of adding auxiliary such as "I am like rabbit too [text 23]". In this sentence, the student adds auxiliary "am" before the ordinary verb and causes the sentence incorrect. Other students add inflectional morpheme to verb, such as "Doraemon can moves... [Text 12]". In this sentence, the student adds inflectional morpheme $-\mathrm{s}$ to the verb although the verb is preceded by modal auxiliary. It is an error, because although the subject is singular, if there is a modal auxiliary, the verb following it should be the base form. Addition error was also investigated by Gunawan. He found a student who wrote "I am met my uncle...". He marked it as an error, which is an additional error because of the existence of an auxiliary verb before the main verb. The correct one is "I met my uncle..." According to him, the auxiliary verb should be deleted to make the right language system (Gunawan, Indah, \& Mulyani, 2018: 155). It is in line with the finding and discussion for this study.

The next error found is the misformation error. The students used some words which is inappropriate or in the wrong form. Some of them include regularization errors, archi-forms, and alternating forms. The example of regularization errors occurs in this sentence, "She teach $\underline{s} . .$. [Text 20]". The error exists in the word "teachs", it happens because the student adds inflectional $-\mathrm{s}$ to the word which should be added with -es. Another example is "Ibu Fitri haves... [Text 20]". The student adds an inflectional 
morpheme for irregular word, in this case, is the use of "haves" instead of "has". While for archi-forms error can be seen in this example, "I walking... [Text 24]". In this case, The student uses present participle form instead of verb base. Next is alternating form error; for example, "I photo are... [Text 15]". In this sentence, the student uses subject "I" instead of the possessive pronoun "My", the correct one should be "My photo is ...". Such kinds of error are often found by other researchers, like Gunawan who found "my" instead of "me" for the sentence "He give me a cat" (Gunawan et al., 2018: 156; Mali \& Yulia, 2015: 24; Mesrawati \& Narius, 2019: 402).

The last kind of error is a misordering error. There are only 3 items of error in this category; for instance, "My cat is name Uzy [Text 18]". In this sentence, the student misorders between subject and verb, the correct structure should be "My cat name is Uzy". This kind of error is rarely found in some studies, moreover study with high-level students.

\section{The Factors cause the Subject-Verb Agreement Errors on Students' Writing}

In the finding, it has been stated that there are two main causes of the subject-verb agreement errors among the students in the eighth grade in MTs Sunan Kalijaga. The errors: omission, addition, misformation, even misordering errors are caused by word for word translation which is done by the students and the lack of grammar.

Regarding the result above, it can be analyzed more based on the theory about factors that can cause the errors, proposed by Brown. He states that there are four kinds of factors that can influence someone in making errors, they are Interlingual transfer, intralingual transfer, the context of learning, and communication strategies. Among the four factors above, two factors are in line with the result of the research. Those are interlingual transfer and intralingual transfer.

The first, interlingual transfer relates to transferring the first language system by using the second language. In this case, the students translate the Indonesian text into English text word by word and the grammar or system used still following the first language. Such as in the use of an auxiliary verb. There are still many students who omit the use of the auxiliary verb in a sentence, because they only follow the Indonesian text, such as the sentence, "She thin, she beautiful too [Text 10]". In this sentence, there is no auxiliary verb used, because it is still influenced by the first language which equals with "Dia kurus, dia cantik juga". She still uses the system of the first language which only mentions the subject and the complement. This problem is supported by other studies which stated that the student was still influenced their first language or they might forget to apply the required rules in a sentence they wrote because they remembered their first language system (Mali \& Yulia, 2012, p. 25) (Mali \& Yulia, 2015: 25).

The Second, intralingual transfer relates to the use of a second language system in which the students apply a rule for construction which has a different rule. It happens 
because they know a particular rule and uses it inappropriately. It occurs in some students' writing, such as in the sentence which contains auxiliary and verb although the auxiliary should not appear in this construction, that is "I am like Arab in school [Text 1]". Similarly, in this sentence "I'm like flower [Text 22]". Another example is the sentence "She teachs Indonesia language [Text 20]". In this sentence, the student applies the rule of adding -s to indicate singular verb without knowing that word ending in "ch" must be followed by -es. It is caused by misusing a rule in other construction. In other research, Nurjanah also discovered same problem. In her view, English certainly has its own patterns that often confusing the students. Therefore, they use both to be and verb in a sentence, like "It is has...." (Nurjanah, 2017: 23). The students assume that they need to write both to be and verb in the sentence.

From those explanations, it is clear that the errors made by the students are caused by the influence of the first language in the second language (interlingual transfer), and intralingual transfer which relates to applying the inappropriate rule for construction.

\section{CONCLUSION}

The research revealed that among 25 students' writing descriptive text at the eighth grade in MTs Sunan Kalijaga Larangan Luar Larangan, there are 161 errors which are found by the researcher in subject-verb agreement. The errors cover the four kinds of the error itself, they are omission, addition, misformation, and misordering. Specifically, there are 92 omission errors, 22 addition errors, 44 misformation errors, and 3 misordering errors. From this data, it can be known that the highest number of errors that are made by the students is in omission error. Besides, the researcher also found that two main factors cause the students to make those errors in their writing, they are word for word translation which includes interlingual transfer, and the lack of grammar which includes an intralingual transfer. By knowing the subject-verb agreement errors within the students' writing and the factors which influence them, it should be a reflection for the students about their mastery, so that they can learn more about an auxiliary, singular and plural noun, even tenses. While for the teacher can set a better teaching-learning process.

\section{REFERENCES}

AU, B. (2010). The Common Vocabulary Book. Kediri: KRC Publishing.

Basri, H. (2009). Structure: An Analysis of English Grammar Problem. Pamekasan: STAIN Pamekasan press.

Brown, H. D. (2007). Principles of Language Learning and Teaching. New York: Pearson Education.

Chele, M. I. (2015). An Analysis of Subject Agreement Errors in English: The Case of Third Year Students at the National University of Lesotho. Ghana Journal of Linguistics, 4(1), 32-40. doi: 10.4314/gjl.v4i1. 
Nafisatul Hasanah \& Mosleh Habibullah, The Analysis of Subject-Verb Agreement Errors ...

Djuharie, O. S. (2008). Functional English Grammar. Bandung: Yrama Widya.

Dulay, H., Burt, M., \& Krashen, S. (1982). Language Two. Oxford: Oxford University Press.

Eastwood, J. (1994). Oxford Guide to English Grammar. Oxford: Oxford University Press.

Eastwood, J. (2008). Oxford Learner's Pocket grammar. Oxford: Oxford University Press.

Ellis, R. (1997). Second Language Acquisition. Oxford: Oxford University Press.

Ellis, R. (2015). Understanding Second Language Acquisition. Oxford: Oxford University Press.

Fanani, A. (2014). Complete Guide for Basic English Grammar. Jogjakarta: Literindo.

Gunawan, R., Indah, R. L., \& Mulyani, P. (2018). Error Analysis of Subject-Verb Agreement Made by Students in Meurandeh Langsa. Language Literacy: Journal of Linguistics, Literature, and Language Teaching, 2(2), 157-165. doi: 10.30743/ll.v2i2.571

Klingner, J. K., Vaughn, S., \& Boardman, A. (2007). Teaching Reading Comprehension to Students with Learning Difficulties. New York: The Guilford Press.

Mali, Y. C. G., \& Yulia, F. Y. (2012). Students' Subject-Verb Agreement Errors in Paragraph Writing Class. Language and Language Teaching Journal, 15(2), 21-28. doi: 10.24071/llt.2012.150204.

Mbau, A. T., Marhum, M., \& Muhsin. (2014). An Analysis on the Subject-Verb Agreement Errors in Writing Paragraph Made By the Second Semester Students of English Department. E-Journal of English Language Teaching Society, 2(2), 1-15. doi: 10.22487\%2Fj23341841.2014.v2.i2.3036.

Mesrawati, \& Narius, D. (2019). Students' Subject Verb Agreement Error in Writing Recount Text Made By Senior High School Students. Journal of English Language Teaching, 8(3), 309-407. doi: 10.24036/jelt.v8i3.105499.

Miles, M. B., Huberman, A. M., \& Saldaña, J. (2014). Qualitative Data Analysis: A Methods Sourcebook (3rd ed.). Thousand Oaks, Califorinia: SAGE Publications, Inc.

Nurjanah, S. (2017). An Analysis of Subject-Verb Agreement Errors on Students' Writing. ELT-Echo, 2(1), 13-15. doi: 10.24235\%2Feltecho.v2i1.1590.

Reid, J. M. (1982). The Process of Composition. United States: Prentice Hall, Inc.

Richards, J. C. (Ed.). (1974). Error Analysis. London: Longman.

Roberts, P. (1954). Understanding Grammar. United States: Harper \& Row Publisher.

Roziqin, B. (2013). Joss Bahasa Inggris dalam 30 Hari. Jogjakarta: Think.

Straus, J. (2008). Buku Panduan Grammar \& Punctuation. Jakarta: Indeks.

Thornbury, S. (1999). How to Teach Grammar. London: Pearson.

Vince, M. (2008). Macmillan English Grammar in Context. Oxford: Macmillan Education.

Wahyudi, R. (2012). Error Analysis on Subject-Verb Agreement: The Case of a University Student in Indonesia. Research on Humanities and Social Science, 2(4), 20-25. Retrieved from https://www.academia.edu/1640877/Error_analysis_of_Subject_Verb_agreement

Zemach, D. E., \& Rumisek, L. A. (2005). Academic Writing from Paragraph to Essay. Oxford: Macmillan Education. 